\title{
Liver cancer with huge nasal alar metastasis
}

\author{
Yanlin Lu, Fang Lou \\ Department of Medical Oncology, Affiliated Dongyang Hospital of Wenzhou Medical University, Dongyang, China \\ Correspondence to: Fang Lou. Department of Medical Oncology, Sir Run Run Shaw Hospital, Medical School of Zhejiang University, Hangzhou \\ 310000, China. Email: luyanlintj@163.com.
}

Submitted May 28, 2020. Accepted for publication Jul 03, 2020.

doi: 10.21037/hbsn-20-501

View this article at: http://dx.doi.org/10.21037/hbsn-20-501

A 29-year-old man was presented to the emergency department with a dull pain in the right upper abdomen for 2 days. He had a history of chronic infection with hepatitis B virus (HBV) for 11 years. The abdominal computed tomography (CT) scan showed multiple low-density nodules fused into a clump, with sizes ranging from approximately $6-13 \mathrm{~cm}$ in the left liver. Postoperative pathology confirmed advanced hepatocellular carcinoma with lung metastatic tumors. After 36 months' systematic treatment, the patient experienced a nasal alar mass growing rapidly (Figure 1A,B). The CT scan of the paranasal sinus demonstrated a $33 \mathrm{~mm} \times 24 \mathrm{~mm}$ mass on the left nasal alar (Figure 1C). The biopsy pathology was consistent with metastatic hepatocellular carcinoma (Figure 1D). The patient has received regular chemotherapy with good performance status recently. This is the first case of liver cancer with such a huge nasal alar metastasis.
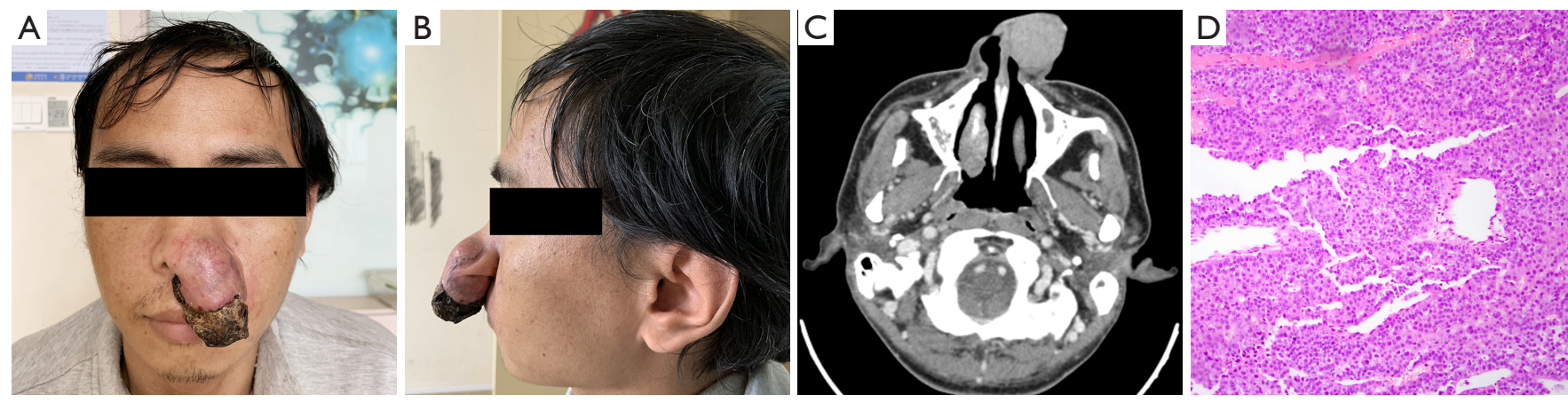

Figure 1 Pictures of nasal alar metastatic mass (A,B); CT scan of the paranasal sinus showing a huge mass on the left nasal alar (C); pathological picture (HE, 100x) of nasal alar biopsy (D).

\section{Acknowledgments}

Funding: None.

\section{Footnote:}

Provenance and Peer Review: This article was a standard submission to the journal Hepatobiliary Surgery and Nutrition. The article did not undergo external peer review.
Conflicts of Interest: Both authors have completed the ICMJE uniform disclosure form (available at https://hbsn. amegroups.com/article/view/10.21037/hbsn-20-501/coif). The authors have no conflicts of interest to declare.

Ethical Statement: The authors are accountable for all aspects of the work in ensuring that questions related to the accuracy or integrity of any part of the work are appropriately investigated and resolved. Written informed 
consent was obtained from the patient for publication of this manuscript and any accompanying images.

Open Access Statement: This is an Open Access article distributed in accordance with the Creative Commons Attribution-NonCommercial-NoDerivs 4.0 International License (CC BY-NC-ND 4.0), which permits the non- commercial replication and distribution of the article with the strict proviso that no changes or edits are made and the original work is properly cited (including links to both the formal publication through the relevant DOI and the license). See: https://creativecommons.org/licenses/by-nc$\mathrm{nd} / 4.0 /$.
Cite this article as: $\mathrm{Lu} \mathrm{Y,} \mathrm{Lou} \mathrm{F.} \mathrm{Liver} \mathrm{cancer} \mathrm{with} \mathrm{huge} \mathrm{nasal}$ alar metastasis. HepatoBiliary Surg Nutr 2021;10(1):151-152. doi: 10.21037/hbsn-20-501 